\title{
SURVEI KESEHATAN HIDUNG ANAK PASAR BERSEHATI KOMUNITAS DINDING MANADO
}

\author{
${ }^{1}$ Rosari Iwawo \\ ${ }^{2}$ Steward Mengko \\ ${ }^{2}$ Julied Dehoop \\ ${ }^{1}$ Kandidat Skripsi Fakultas Kedokteran Universitas Sam Ratulangi Manado \\ ${ }^{2}$ Bagian THT-KL Fakultas Kedokteran Universitas Sam Ratulangi Manado \\ Email: riwawo11_207@yahoo.com
}

\begin{abstract}
Health problems that occur in children can be considered as a manifestation of lack of knowledge and poor attitudes of parents in taking care of their children. It is suspected that the main triggers of those problems are negative condition and circumstance. This study aimed to obtain the nose health status of children at Bersehati Market Dinding Manado Community. This was a descriptive study with a cross sectional design. Nose health status was determined by examining the nasal cavity, conchae, mucous layer, secret, septum, and post nasal drip. The results showed that most of the children had normal nose health examination. Conclusion: Nose health status of most children at Bersehati Market Dinding Manado Community was good.
\end{abstract}

Keywords: nose health, nasal examination

\begin{abstract}
Abstrak: Masalah kesehatan pada anak-anak dapat dipandang sebagai perwujudan dari rendahnya pengetahuan dan sikap orang tua tentang pola asuh anak. Pemicu utamanya diduga ialah situasi dan kondisi yang negatif. Penelitian ini bertujuan untuk mendapatkan status kesehatan hidung anak-anak Pasar Bersehati Komunitas Dinding Manado. Penelitian ini menggunakan metode deskriptif dengan desain potong lintang. Gambaran kesehatan hidung setiap sampel dilihat dengan memeriksa kavum nasi, konka, mukosa, sekret, septum, dan post nasal drip. Hasil pemeriksaan hidung menunjukkan bahwa sebagian besar gambaran kesehatan hidung pada anak-anak Pasar Bersehati Komunitas Dinding Manado normal. Simpulan: Sebagian besar anak di Komunitas Pasar Bersehati Dinding Manado memiliki status kesehatan hidung baik.
\end{abstract}

Kata kunci: kesehatan hidung, pemeriksaan hidung

Kesehatan mempunyai peran besar dalam meningkatkan derajat hidup masyarakat, maka negara berupaya menyelenggarakan pelayanan yang sebaik-baiknya melalui upaya meningkatkan kesehatan, mencegah, dan mengobati penyakit, serta memulihkan kesehatan perseorangan, kelompok, atau masyarakat. ${ }^{1}$

Masalah kesehatan yang terjadi pada anak-anak dapat dipandang sebagai perwujudan dari rendahnya pengetahuan dan sikap orang tua tentang pola asuh anak. Pemicu utamanya diduga ialah situasi dan kondisi yang negatif. Pengetahuan tentang perawatan kesehatan anak merupakan aspek utama dan esensial dalam keluarga yang harus di miliki oleh orang tua. karena mereka bertanggung jawab secara kodrati dalam mengasuh anak. Keberadaan anakanak pasar tampaknya telah menjadi fenomena keseharian kota-kota besar di Indonesia. Anak adalah generasi penerus yang akan menjadi kekuatan suatu bangsa di masa depan. Anak yang hidup dengan lingkungan pasar berbeda dengan anak yang berada jauh dari kehidupan pasar. 
Sosial, ekonomi, kesehatan, pendidikan pun berbeda dengan anak yang hidup diluar lingkungan pasar. Bermacam-macam faktor yang mendukung alasan mereka untuk terjun ke pasar demi mencari nafkah salah satunya yaitu pengaruh dari teman dan disuruh oleh orang tua tetapi yang menjadi faktor utama menjadi anak jalanan ialah

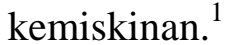

Hidung dibentuk oleh dua bagian yaitu bagian mobil (kartilago) dan bagian yang tetap (tulang). Secara fisiologi fungsi hidung untuk menghangatkan, membersihkan dan melembabkan udara pernafasan. ${ }^{2}$ Hidung merupakan organ yang terlihat kecil namun penting bagi manusia dan merupakan salah satu organ penting yang menjadi pelindung tubuh terhadap lingkungan yang tidak menguntungkan. Hidung terkadang dapat tersumbat oleh karena berbagai penyebab seperti alergi, kelainan anatomi, ataupun massa pada hidung. Penyakit-penyakit yang dapat timbul pada hidung antara lain rinitis alergi maupun vasomotor, deviasi septum, dan polip hidung. ${ }^{3}$

\section{METODE PENELITIAN}

Penelitian ini bersifat deskriptif dengan desain potong lintang. Tempat penelitian dilakukan di Pasar Bersehati Komunitas Dinding Manado pada tanggal 15 November 2014. Sampel penelitian ini ialah anak-anak yang bersedia untuk dilakukan pemeriksaan THT-KL. Variabel penelitian diantaranya jenis kelamin dan hasil pemeriksaan status kesehatan hidung

\section{HASIL PENELITIAN}

Pada penelitian terhadap anak-anak Pasar Bersehati Komunitas Dinding Manado didapatkan yang terbanyak yaitu siswa perempuan 18 orang (56,3\%) sedangkan siswa laki-laki 14 orang $(43,8 \%)$ (Tabel 1).

Pada pemeriksaan kesehatan kavum nasi semua sampel memperlihatkan kavum nasi lapang baik kanan maupun kiri pada 32 orang (100,0\%) (Tabel 2).

Pada pemeriksaan kesehatan konka didapatkan hasil terbanyak yaitu normal 28 anak (87,5\%) pada konka kanan dan 30 anak $(93,8 \%)$ pada konka kiri. Kelainan berupa udim 2 anak (6,3\%) pada konka kanan, konka hiperemis 2 anak (6,3\%) pada konka kanan dan 2 anak (6,3\%) pada konka kiri (Tabel 3).

Tabel 1. Distribusi berdasarkan jenis kelamin anak-anak Pasar Bersehati Komunitas Dinding Manado

\begin{tabular}{ccc}
\hline Jenis kelamin & $\mathrm{N}$ & $\%$ \\
\hline Laki-laki & 14 & 43,8 \\
Perempuan & 18 & 56,3 \\
Total & 32 & 100,0 \\
\hline
\end{tabular}

Tabel 2. Distribusi berdasarkan keadaan kavum nasi anak-anak Pasar Bersehati Komunitas Dinding Manado

\begin{tabular}{ccccc}
\hline Kavum & \multicolumn{2}{c}{$\mathrm{N}$} & \multicolumn{2}{c}{$\%$} \\
\cline { 2 - 5 } Nasi & Kanan & Kiri & Kanan & Kiri \\
\hline Lapang & 32 & 32 & 100,0 & 100,0 \\
Sempit & 0 & 0 & 0,0 & 0,0 \\
Massa & 0 & 0 & 0,0 & 0,0 \\
Total & 32 & 32 & 100,0 & 100,0 \\
\hline
\end{tabular}

Tabel 3. Distribusi berdasarkan keadaan konka anak-anak Pasar Bersehati Komunitas Dinding Manado

\begin{tabular}{ccccc}
\hline Konka & \multicolumn{2}{c}{$\mathrm{N}$} & \multicolumn{2}{c}{$\%$} \\
\cline { 2 - 5 } & Kanan & Kiri & Kanan & Kiri \\
\hline Udim & 2 & 0 & 6,3 & 0,0 \\
\hline Hiperemis & 2 & 2 & 6,3 & 6,3 \\
\hline Pucat & 0 & 0 & 0,0 & 0,0 \\
\hline Hipertrofi & 0 & 0 & 0,0 & 0,0 \\
\hline Atrofi & 0 & 0 & 0,0 & 0,0 \\
\hline Normal & 28 & 30 & 87,5 & 93,8 \\
\hline Total & 32 & 32 & 100,0 & 100,0 \\
\hline
\end{tabular}

Pada pemeriksaan kesehatan mukosa kavum nasi didapatkan hasil terbanyak normal baik mukosa kanan maupun kiri yaitu 30 anak (93,8\%), kelainan hiperemis 2 anak (6,3\%) pada mukosa kanan dan 2 anak (6,3\%) pada mukosa kiri (Tabel 4).

Pada pemeriksaan kesehatan sekret kavum nasi didapatkan hasil terbanyak yaitu tidak ada sekret 27 anak $(84,4 \%)$ pada hidung kanan dan 28 anak $(87,5 \%)$ pada hidung kiri. Didapatkan juga sekret serus 2 
anak (6,3\%) pada hidung kanan dan 1 anak $(3,1 \%)$ pada hidung kiri. Selain sekret serus didapatkan hasil sekret mukoid 3 anak (9,4\%) baik hidung kiri maupun hidung kanan (Tabel 5).

Tabel 4. Distribusi berdasarkan keadaan mukosa anak-anak Pasar Bersehati Komunitas Dinding Manado

\begin{tabular}{ccccc}
\hline \multirow{2}{*}{ Mukosa } & \multicolumn{2}{c}{$\mathrm{N}$} & \multicolumn{2}{c}{$\%$} \\
\cline { 2 - 5 } & Kanan & Kiri & Kanan & Kiri \\
\hline Normal & 30 & 30 & 93,8 & 93,8 \\
Hiperemis & 2 & 2 & 6,3 & 6,3 \\
Livide & 0 & 0 & 0,0 & 0,0 \\
Total & 32 & 32 & 100,0 & 100,0 \\
\hline
\end{tabular}

Tabel 5. Distribusi berdasarkan sekret anakanak Pasar Bersehati Komunitas Dinding Manado

\begin{tabular}{ccccc}
\hline \multirow{2}{*}{ sekret } & \multicolumn{2}{c}{$\mathrm{N}$} & \multicolumn{2}{c}{$\%$} \\
\cline { 2 - 5 } & Kanan & Kiri & Kanan & Kiri \\
\hline Tidak ada & 27 & 28 & 84,4 & 87,5 \\
\hline Serus & 2 & 1 & 6,3 & 3,1 \\
\hline Mukoid & 3 & 3 & 9,4 & 9,4 \\
\hline Purulen & 0 & 0 & 0,0 & 0,0 \\
\hline Total & 32 & 32 & 100,0 & 100,0 \\
\hline
\end{tabular}

Pada pemeriksaan kesehatan septum didapatkan hasil terbanyak yaitu normal 31 anak (96,9\%) pada septum kanan dan 30 anak (93,8\%) pada septum kiri. Terdapat juga kelainan deviasi 1 anak (3,1\%) pada septum kanan dan 2 anak (6,3\%) pada septum kiri (Tabel 6).

Tabel 6. Distribusi berdasarkan septum anakanak Pasar Bersehati Komunitas Dinding Manado

\begin{tabular}{ccccc}
\hline \multirow{2}{*}{ Septum } & \multicolumn{2}{c}{$\mathrm{N}$} & \multicolumn{2}{c}{$\%$} \\
\cline { 2 - 5 } & Kanan & Kiri & Kanan & Kiri \\
\hline Deviasi & 1 & 2 & 3,1 & 6,3 \\
\hline Abses & 0 & 0 & 0,0 & 0,0 \\
\hline Hematoma & 0 & 0 & 0,0 & 0,0 \\
\hline Normal & 31 & 30 & 96,9 & 93,8 \\
\hline Total & 32 & 32 & 100,0 & 100,0 \\
\hline
\end{tabular}

Pada pemeriksaan post nasal drip anak-anak Pasar Bersehati Komunitas Dinding Manado tidak ditemukan kelainan pada 32 anak (100,0\%) baik pada hidung kanan maupun kiri (Tabel 7).
Tabel 7. Distribusi berdasarkan post nasal drip anak-anak Pasar Bersehati Komunitas Dinding Manado

\begin{tabular}{ccccc}
\hline Post nasal & \multicolumn{2}{c}{$\mathrm{N}$} & \multicolumn{2}{c}{$\%$} \\
\cline { 2 - 5 } drip & Kanan & Kiri & Kanan & Kiri \\
\hline Ada & 0 & 0 & 0,0 & 0,0 \\
Tidak ada & 32 & 32 & 100,0 & 100,0 \\
Total & 32 & 32 & 100,0 & 100,0 \\
\hline
\end{tabular}

\section{BAHASAN}

Penelitian yang dilakukan terhadap anak-anak Pasar Bersehati Komunitas Dinding Manado menggunakan desain potong lintang. Berdasarkan karakteristik jenis kelamin yang bersedia mengikuti penelitian ini 14 anak laki-laki (43,8\%) dan 18 anak perempuan (56,3\%). Berdasarkan pemeriksaan kavum nasi didapatkan keadaan terbanyak yaitu normal 32 orang (100,0\%) pada kavum nasi kanan dan kiri.

Polip nasi merupakan salah satu kelainan yang dapat terjadi pada kavum nasi. Etiologi pasti dan mekanisme perkembangan polip nasi masih belum diketahui. $^{4}$ Pada pemeriksaan konka didapatkan hasil terbanyak normal 28 anak (87,5\%) pada konka kanan dan 30 anak (93,8\%) pada konka kiri. Kelainan yang ditemukan yaitu udim 2 anak (6,3\%) pada konka kanan dan kedua konka terdapat hiperemis 2 anak (6,3\%) pada konka kanan dan 2 anak (6,3\%) pada konka kiri. Salah satu kelainan yang dapat terjadi pada konka yaitu hipertrofi konka yang dapat menyebabkan obstruksi saluran pernapasan atas dan semua gejala penyerta yang bervariasi dari kelainan yang kurang disadari sampai yang sangat mengganggu perasaan sehat. ${ }^{4}$

Pemeriksaan mukosa kavum nasi didapatkan hasil terbanyak normal pada mukosa kanan maupun kiri pada 30 anak (93,8\%) dan terdapat kelainan hiperemis 2 anak (6,3\%) pada mukosa kanan dan 2 anak (6,3\%) pada mukosa kiri. Mukosa hidung pada pasien alergi biasanya basah, pucat dan berwarna merah jambu keabuan. Konka tampak membengkak. Jika terdapat infeksi penyerta, sekret dapat bervariasi mulai dari encer dan mukoid hingga kental dan purulen. Pada saat yang sama, mukosa 
menjadi merah dan meradang, terbendung atau bahkan kering sama sekali. ${ }^{5}$ Pada pemeriksaan sekret ditemukan hasil terbanyak yaitu tidak ada sekret 27 anak $(84,4 \%)$ pada hidung kanan dan 28 anak $(87,5 \%)$ pada hidung kiri. Didapatkan juga sekret serus 2 anak (6.3\%) pada hidung kanan dan 1 anak (3,1\%) pada hidung kiri. Selain sekret serus didapatakan hasil sekret mukoid 3 orang $(9,4 \%)$ baik hidung kiri maupun hidung kanan. Pada pemeriksaan kesehatan septum didapatkan hasil hasil terbanyak yaitu normal 31 anak (96,9\%) pada septum kanan dan 30 anak (93,8\%) pada septum kiri. Terdapat juga kelainan yaitu deviasi 1 anak (3,1\%) pada septum kanan dan 2 anak (6,3\%) pada septum kiri. Salah satu kelainan pada septum yaitu deviasi septum. Bentuk septum normal ialah lurus di tengah rongga hidung tetapi pada orang dewasa biasanya septum nasi tidak lurus sempurna di garis tengah. Deviasi septum yang ringan tidak akan mengganggu, akan tetapi bila deviasi itu cukup berat, menyebabkan penyempitan pada satu sisi hidung. ${ }^{6}$

Pada pemeriksaan post nasal drip tidak ditemukan dengan hasil terbanyak yaitu 32 anak (100,0\%) pada hidung kanan maupun kiri. Salah satu penyakit dengan gejala post nasal drip yaitu rhinitis alergi. Insiden rhinitis alergi yang tepat tidak diketahui tetapi tampaknya ditemukan pada sekitar $10 \%$ dari populasi umum. Patogenesis rhinitis alergi diduga melibatkan antibodi reaginik, basofil, sel mast, dan pelepasan mediator seperti histamin, prostaglandin, dan leukotrien, yang bekerja pada kavum nasi dan menimbulkan manifestasi klinis. ${ }^{5}$

\section{SIMPULAN}

Berdasarkan hasil penelitian pada anak-anak Pasar Bersehati Komunitas Dinding Manado dapat disimpulkan bahwa sebagian besar anak memiliki status kesehatan hidung baik. Hal ini menunjuk- kan bahwa keadaan lingkungan atau tempat tinggal yang kotor bukan menjadi suatu masalah utama jika kita dapat menjaga kebersihan diri khususnya kebersihan hidung dan mandi dengan air yang bersih.

\section{SARAN}

Perlu ditingkatkan usaha promosi kesehatan hidung pada anak-anak pasar maupun anak-anak usia sekolah.

Penelitian ini dapat dijadikan sebagai langkah awal penelitian selanjutnya dalam melakukan survei kesehatan hidung, khususnya dikalangan anak-anak panti asuhan dan anak-anak jalanan.

\section{DAFTAR PUSTAKA}

1. Azikin N. Profil Kesehatan Kota Makasar. Dinas Kesehatan Kota Makasar. Makasar, 2008; p. 55-8.

2. Almeida FS, Minarro LL, Pialarissi PB, Shirane E. Surgical correction of the saddle nose: case report. Int Arch of Otorhinolaryngology 2009;13(4):1-6.

3. Hilger PA. Hidung: anatomi dan fisiologi terapan. In: Adams GL, Boies LR, Higler PA, editors. Boies Buku Ajar Penyakit THT (Edisi 6). Jakarta: EGC, 1997; p. 173-88.

4. Nizar NW, Mangunkusumo E. Kelainan Septum. In: Soepardi HEA, Iskandar HN, penyunting. Buku Ajar Ilmu Penyakit Telinga-hidung-tenggorok (Edisi 3). Jakarta: Balai penerbit FKUI, 1997; p. 100.

5. Hilger PA, Blumenthal MN. Hidung dan sinus paranasalis. In: Adams GL, Boies LR, Higler PA, penyunting. Buku Ajar Penyakit THT (Edisi 6). Jakarta: EGC, 1997; p. 173-240.

6. Soetjipto D, Mangunkusumo E, Wardani RS. Hidung. In: Soepardi EA, Iskandar HN, Bashiruddin J, Restuti RD, peyunting. Buku Ajar Ilmu Kesehatan Telinga Hidung Tenggorok (Edisi 3). Jakarta: Balai penerbit FKUI, 1997. p. 91-6. 